\title{
Latent Virus
}

National Cancer Institute

\section{Source}

National Cancer Institute. Latent Virus. NCI Thesaurus. Code C14367.

Virus integrated within host genome but inactive; may be reactivated by stress such as ultraviolet irradiation. 